\title{
The Impact of Innovation and Personal Control on Micro- Entrepreneurs' Performance in Sabah
}

Deewasnari Muddat, Sylvia Nabila Azwa Ambad, Rosmimah Mohd Roslin, Nelson Lajuni

To Link this Article: http://dx.doi.org/10.6007/IJARBSS/v10-i12/8395

DOI:10.6007/IJARBSS/v10-i12/8395

Received: 13 November 2020, Revised: 06 December 2020, Accepted: 16 December 2020

Published Online: 02 January 2021

In-Text Citation: (Muddat et al., 2020)

To Cite this Article: Muddat, D., Ambad, S. N. A., Roslin, R. M., \& Lajuni, N. (2020). The Impact of Innovation and Personal Control on Micro-Entrepreneurs' Performance in Sabah. International Journal of Academic Research in Business and Social Sciences, 10(12), 1263-1282.

\section{Copyright: (c) 2020 The Author(s)}

Published by Human Resource Management Academic Research Society (www.hrmars.com)

This article is published under the Creative Commons Attribution (CC BY 4.0) license. Anyone may reproduce, distribute, translate and create derivative works of this article (for both commercial and non-commercial purposes), subject to full attribution to the original publication and authors. The full terms of this license may be seen at: http://creativecommons.org/licences/by/4.0/legalcode

\section{Vol. 10, No. 12, 2020, Pg. 1263 - 1282}

Full Terms \& Conditions of access and use can be found at http://hrmars.com/index.php/pages/detail/publication-ethics 


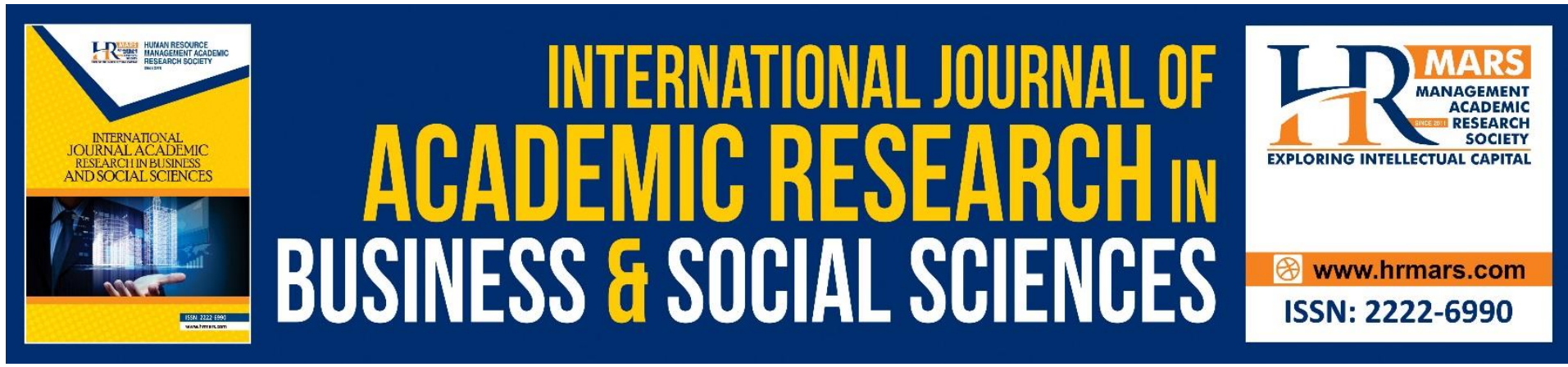

\title{
The Impact of Innovation and Personal Control on Micro-Entrepreneurs' Performance in Sabah
}

\author{
Deewasnari Muddat ${ }^{1}$, Sylvia Nabila Azwa Ambad², Rosmimah \\ Mohd Roslin ${ }^{3}$, Nelson Lajuni ${ }^{4}$ \\ Universiti Teknologi MARA ${ }^{1}$, Universiti Teknologi MARA ${ }^{2}$, Universiti Teknologi MARA ${ }^{3}$, \\ Universiti Malaysia Sabah ${ }^{4}$ \\ Email: deewasnarimuddat@gmail.com¹, nabila1793@uitm.edu.my², \\ rosmimah@uitm.edu.my33,nelsonl@ums.edu.my ${ }^{4}$
}

\begin{abstract}
Purpose: This paper aims to examine the innovation and personal control impact on microbusiness performance in Sabah, Malaysia.

Research Methodology: The paper adopts non-probability known as a purposive sampling method in the selection of micro-businesses. The sample consists of micro business owners/entrepreneurs under the TEKUN financing scheme throughout Sabah. A survey using self-conducted questionnaires structured on a 7-point Likert scale is conducted through the distribution of 600 questionnaires, and subsequently, a total of 525 questionnaires are returned. The EAO dimensions assessed in the paper are innovation and personal control. Data collected are analysed using the SEM-PLS technique through the SmartPLS 3.3.2 software.

Results: The results show that innovation and personal control are positively correlated with micro-business performance. Nevertheless, this study found that the level of performance among entrepreneurs is moderately low.

Limitations: The theoretical implication of this paper is that it provides supports to some of the previous findings and arguments that EAO play an essential role in ensuring microentrepreneurs achieving better business performance.
\end{abstract}

Contribution: From a practical perspective, the findings of this paper help entrepreneurs, owners, government agencies, and other stakeholders to understand the critical role of EAO in improving the business performance of micro-business in Malaysia.

Keywords: Entrepreneurial Attitude Orientation, Micro Entrepreneur, Business Performance, Innovation, Personal Control.

\section{Introduction}

The concept of entrepreneurship has long been admitted as an essential contributor to the various continuities that affect the economic growth of a country. Malaysia is no exception to this positive development. Therefore, the Malaysian government has extended various assistance to entrepreneurs to grow their business. However, many micro-enterprises in Malaysia often failed to achieve their objectives (Abdullahi and Zainol, 2016) and their 
performance continues to be unsatisfactory (Mohamad, Rizal, Quoquab, Juhdi, and Sahimi, 2016; Chin and Lim (2018). As a result, a total of 79,310 establishments from various businesses have been discontinued in Malaysia since 2002 (CCM, 2002). The increase in enterprise layoffs with declining business performance is deemed crucial issues. It needs to be addressed systematically by investigating the root source of the failure among these microentrepreneurs.

Accordingly, there is a need to examine the business performance contributing factors, particularly among micro-enterprises, since research focusing on micro-business is still lacking. Previous studies have shown that among the main factors of business failure is the negative attitude of the entrepreneur (Politis and Gabrielsson, 2009; Jamak et al., 2011). Thus, this study aims to examine the effect of Entrepreneurial Attitude Orientation (EAO) on microenterprises business performance. EAO has been shown to be consistently and positively related to business performance (Pulka, 2018; Jain, Ali, and Kamble, 2015; Ricard and Saiyed, 2015; Valliere, 2006). For example, the EAO dimensions of personal control and innovation are found to be positively related to the performance of micro-entrepreneurs.

The study conducted by Pulka (2018) demonstrated that there is a significant impact of EAO on micro-entrepreneurs' performance, and suggested future studies to explore and study samples from different parts of the country and urged more replicated research to validate the results of their research. In Malaysia, Keling and Entebang (2017) found that one of the EAO variables of innovation was not significantly associated with the Dayak entrepreneur performance in the state of Sarawak; in contrast, personal control was positively and significantly related to the performance of Dayak entrepreneur. A study by Choe, Loo and Lau (2013) employed a quantitative approach involving 113 SMEs in Malaysia. They found that innovation has the most significant influence on firm performance, followed by self-esteem, personal control, achievement, and recognition of opportunities. However, the findings on the innovation variable between the two studies were inconclusive, although both were studies conducted in Malaysia.

Therefore, this study attempts to determine factors influencing the business performance of micro-entrepreneurs by incorporating two (2) independent variables from previous studies, namely innovation and personal control as predictors. This study will broaden the knowledge and deepen the understanding of business performance studies, particularly in the context of Sabah.

\section{Literature Review and Hypothesis Development}

Generally, all public and private agencies in developed and developing countries have adopted an entrepreneurial attitude orientation (EAO) (Alhnaity, 2018). Consequently, EAO has a profound influence that can change the opinions, beliefs, and purposes of entrepreneurs towards their jobs and businesses (Rauch, Wiklund, Lumpkin, and Frese, 2009). The gap that still exists between concepts and realities in the relationship between entrepreneurial attitudes and business performance has yet to be concluded. Therefore, it is imperative to study the idea of EAO in the context of small businesses in Sabah, Malaysia, based on the following two main factors. 
First, more information is needed to provide an exact EAO aspect. For example, entrepreneurs who do their work are aware of their level of ability, skills, and entrepreneurial activities related to various needs, recognition through self-esteem and business progress (Alhnaity, 2018). Besides, small entrepreneurs need to use this concept to stay competitive and sustainable through the business they have ventured. Significantly, EAO ultimately will result in maximum entrepreneurship, growth and development (Lee and Peterson, 2000). Second, the career choice of an individual is mainly influenced by several factors, such as gender, education, interest, direct and indirect influence of parents, environment, status and perception of society, the return of money, ability and capability (Davidson, 1995). The statement is supported by Kuratko and Hodgetts (2004), who found that career choices depend on significant demographic variables, family status, education, and motivation by others.

There is a lack of studies that show the influence of EAO on business performance, especially Small Medium Enterprises (SMEs), particularly in Sabah. Second, very little is reflected regarding this issue in the current literature. Furthermore, there is a lack of scientific studies on EAO and business performance (Pulka, 2018; Khalid, 2020). Therefore, this study attempts to fill the gap by determining the influence of EAO on the performance of microentrepreneurs in Sabah, Malaysia. There have been numerous discussions on EAO around the world. Still, very few studies were conducted in Malaysia, especially in Sabah, on the direction of micro-entrepreneurial attitudes. Therefore, this research aims to delve deeper into the issue to determine the impact of EAO on the business performance of micro-entrepreneurs; the specific purpose is to explore the relationship between innovation and personal control and their effect on micro-business performance.

The essential role of entrepreneurial attitude orientation (EAO) in improving business performance has been duly recognised (Choe et al., 2013; Ibrahim and Saili, 2017; Pulka, 2018). Entrepreneurial research focusing on attitude was first explored by Olson and Bosserman (1984) and subsequently expanded by Low and MacMillan (1988). The prominent pioneer of attitude is Allport (1935), who defines attitude as "a state of mental readiness of a person organised through experience, giving a dynamic influence on the individual response to all objects and situations related to it. According to Pickens (2005), attitude is a person's beliefs and tendencies, behaving or acting in a certain way, blended through personal knowledge and experience. The attitude towards developing a business should be driven by the targeted objectives (Ajzen and Fishbein, 1987).

This study uses the dimension of Entrepreneurial Attitude Orientation (EAO) developed by Robinson, Stimpson, Huefner, and Hunt, (1991), which is based on the attitude theory explicitly designed to predict entrepreneurial attitudes embedded in an entrepreneur. Individual attitudes are crucial in identifying business activities undertaken (Begley and Boyd, 1988; Koh, 1996). According to Robinson et al. (1991), EAO encompasses individual characteristics, such as innovation, achievement, self-esteem, and personal control. These unique characteristics are capable of predicting entrepreneurial attitudes inherent in individuals (Kollmann, Christofor, and Kuckertz, 2007), which is a predictor of reliable entrepreneurial performance improvement (Covin and Wales, 2012; Krueger et al., 2000; Rauch and Frese, 2007). The structure of the paper is as follows; this section provides an overview of EAO, based on related literature, follows by the impact of EAO business 
performance, conceptual framework of the study, research hypothesis methodology, analysis and results, discussion of findings, conclusions, and finally, research limitations.

\section{Entrepreneurial Attitude Orientation Dimensions}

Robinson, Stimpson, Huefner and Hunt (1991) developed a set of items that purported to measure: (a) Innovation, (b) Personal control, (c) Self-esteem; and, (d) Achievement-theorised components of the focal construct domain, entrepreneurial attitude. The Robinson team successfully distinguished entrepreneurs from non-entrepreneurs in their research context.

In many cases, business-oriented enterprises will discover and develop new market opportunities (Wiklund and Shepherd, 2003). A variety of financial measures were used in another study to assess the performance of the business, such as cash flow, return on assets, and return on equity. Several studies suggest that a mix of financial and non-financial metrics provides a more detailed assessment of the results of the business (Li et al., 2009).

Subjective non-financial metrics include factors, such as perceived market share, perceived growth in revenue, customer satisfaction, loyalty, and brand equity (Li et al., 2009). Murphy et al. (1996) analysed fifty-one (51) published entrepreneurial studies using performance as a dependent variable and found that the most widely considered dimensions of performance are success, efficiency, and benefit.

Efficiency includes specific financial measures, such as return on investment and returns on equity; growth focuses on an increase in sales, employees, or market share; while profit includes return on sales and a net profit margin. Jelenc et al. (2016) pointed out that the dimensions of EAO can lead to market growth. The innovation dimension of the EAO reflects the tendency to engage and promote novelty in the creation and introduction of new products, services, or technologies.

Risk-taking guidance indicates a willingness to engage resources in strategies or projects where the outcome may be highly uncertain. Opportunity refers to the firm's response to promising new products and services. Achievement requires a tendency to confront its opponents explicitly and vigorously. The self-esteem parameter is also given to a person or a group within a company to develop business ideas and goals, and to carry them through until completion.

When new businesses are more capable of innovation, risk-taking, opportunities, and business achievement, micro-business borrowers can gain more competitive advantage and achieve higher firm performance. The practical orientation of an entrepreneurial attitude can be a good predictor of firm performance.

The research adopts the approach by Robinson et al. (1991) using two variables of entrepreneurial attitude orientation, as shown in Figure 1. It is acceptable to have a broader definition of EAO (Antoncic and Hisrich, 2003). Cooper and Gascon (1994) highlighted the individual factors that influence performance, such as experience, education, parental occupation, gender, race, age, and the goals of the entrepreneur. 
Studies on individual factors that influence performance are prevalent, although most of them were conducted in the United States, Canada, and the United Kingdom. This study uses business performance as a dependent variable due to its significance to organisations, individuals, and communities. Business performance is also a result that all entrepreneurs need to examine.

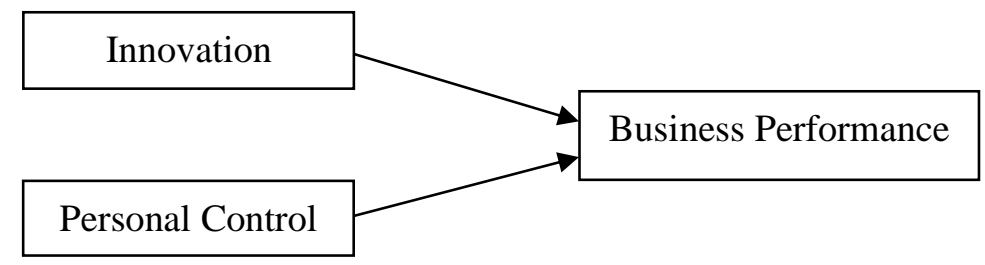

Figure 1: Adapted from Choe et al. (2013)

\section{Conceptual Framework}

For this research, a conceptual framework (see Figure 1) was developed based on the conceptual framework of Choe et al. (2013). Consistent with this research, a conceptual model that specifies how EAO can affect business performance is established. The study will examine the relationship between EAO (independent variables) and business performance (dependent variable). It is crucial to investigate if there is a significant positive relationship between the independent variables and the dependent variable. The conceptual framework consists of two types of variables: independent variable (predictor) and dependent variable (criterion). The predictor in this study is the EAO, while the criterion is the microentrepreneur' business performance. The developed conceptual framework intends to show the influence and effect of the variables.

For this study, the variables in the conceptual framework consist of innovation and personal control, and its impact on micro-entrepreneur' business performance. The two predictors represent the four dimensions of EAO (Robinson et al., 1991). Based on the hypotheses of the study, innovation and personal control positively influenced micro-entrepreneur' business performance. The framework suggested that separately, the dimensions would have an impact on micro-entrepreneur' business performance. Robinson et al. (1991) explained the following: first, innovation in businesses is related to identifying, perceiving, and taking decisive entrepreneurial actions on the business activities in a new and unique method. Second, the perceived personal control of the business outcomes deals with the entrepreneurs' perception of controlling, influencing, and managing their businesses.

\section{Hypotheses Development}

The objective of the study hypotheses is to examine the impact of innovation and personal control on the performance of micro-entrepreneurs that serve as the Entrepreneurial Attitude Orientation (EAO) dimension. EAO influences and improves the business performance of micro-entrepreneurs. EAO enables the resources of micro-entrepreneurs to be managed more effectively and efficiently, both internally and externally. EAO enables better collaboration and coordination among micro-entrepreneurs. Besides, EAO is expected to improve the performance of micro business operations and increase the movement of information that could improve the decision-making process in micro-businesses, leading to an efficient allocation of resources, which in turn, increase productivity and efficiency of micro-businesses. As previously highlighted, the current aspects of the EAO concept illustrate 
individuals' ability to innovate, control, self-esteem, and achievement. Therefore, based on the literature review, this study develops several hypotheses that will guide this research.

\section{Relationship between Innovation and Business Performance}

The first dimension is innovation, which is related to activities, such as developing new products and approaches, exploring new markets and developing new organisations. In other words, innovation refers to an exclusive and unique way to conceptualise and execute business ideas (Drucker, 1985). Innovation is an attempt to create a unique design that is consistent with the latest practices and technologies; it explains the concept and implementation of ideas in new ways. Therefore, this study hypothesises:

H1: Innovation entrepreneurial attitude orientation has a significant effect on microentrepreneur business performance.

\section{Relationship between Personal Control and Business Performance}

Personal control refers to self-control and perceived influence on the success of a business. Personal control gives individuals confidence, commitment, and determination to succeed and to continue their entrepreneurial journey (Choe et al., 2013). Rotter, in his concept of self-control, illustrates the relationship between perception about one's control over one's choices. Life and its subsequent rewards will lead to one's behaviour (Rotter, 1966). Personal control concept refers to the attitude of individuals in dealing with daily affairs in the surrounding community, which, in turn, influences their decisions and actions. The grant receivers must be equipped with confidence, commitment, and determination, which will enable them to continue their entrepreneurial journey (Din et al., 2005). Therefore, this study hypothesises:

H2: Personal Control entrepreneurial attitude orientation has a significant effect on microentrepreneur business performance.

\section{Research Methodology}

This study's sample consists of owners/managers of micro-entrepreneur in Sabah, Malaysia. Six hundred questionnaires were self-administered by the targeted sample. Purposive sampling approach was adopted in the selection of micro-entrepreneur. The sampling method is in line with Bakar, Ramli, Ibrahim, and Muhammad (2017) and Samuel, Ernest, and Awuah (2013). They suggested that a method of purposive sampling can be used when the population of the study is not well-known.

Additionally, the study used the definition given by SME Corporation Malaysia to conduct the research. Micro-enterprise is defined as businesses that employ less than five (5) employees and have less than MYR300,000 worth of assets, excluding lands and buildings. Table 1 depicts the definition of micro-enterprises in Malaysia. 
Table 1: New definition of SMEs in Malaysia effective date: 1 January 2014

\begin{tabular}{lllll}
\hline S/No. Size & Category & Employment & Sales turnover \\
\hline 1. & $\begin{array}{l}\text { Micro } \\
\text { enterprises }\end{array}$ & $\begin{array}{l}\text { Manufacturing / } \\
\text { Services and } \\
\text { Others Sectors }\end{array}$ & $\begin{array}{l}\text { Employees of } \\
\text { less than 5 }\end{array}$ & $\begin{array}{l}\text { Sales turnover of } \\
\text { less than RM300,000 }\end{array}$ \\
\hline & & Manufacturing & $\begin{array}{l}\text { Employees from } \\
5 \text { to less than 75 }\end{array}$ & $\begin{array}{l}\text { Sales turnover from } \\
\text { RM300,000 to less than } \\
\text { RM15 mil }\end{array}$ \\
\cline { 3 - 5 } 2. Small & enterprises & Services and & Employees from & $\begin{array}{l}\text { Sales turnover from } \\
\text { RM300,000 to less than } \\
\end{array}$ \\
\cline { 3 - 5 } & Others Sectors & 5 to less than 30 & RM3 mil \\
\hline
\end{tabular}

Sources: https://www.smecorp.gov.my

Data Collection Procedure, Variable Measurement, and Method of Data Analysis

A structured self-administered questionnaire was used to collect data from respondents. The questionnaire is based on a 7-point Likert scale, ranging from strongly disagree to strongly agree. Meanwhile, the measurement to measure EAO is adapted from an entrepreneurial attitude orientation scale developed by Robinson et al. (1991). This study replicates the approach used by Breckler (1984), Chaiken and Stangor (1987) and Shaver (1987); they maintain that EAO is multidimensional that comprise innovation, personal control, selfesteem, and achievement. Innovation is measured using five (5) items, and personal control three (3) items. While MEs performance was measured using an instrument adapted from the work of Suliyanto and Rahab (2012) and the modified version contains nine items. SPSS version 26 was applied to analyse data collected from the respondents, which includes descriptive and correlation analysis.

The targeted sample of this study is the micro-entrepreneur in Sabah, Malaysia. The questionnaire adapted from (Robinson et al.,1991) and (Ibrahim and Saili, 2017) toolkits for measuring EAO and micro-entrepreneur performance consists of non-financial measures, namely business performance (Suliyanto and Rahab. 2012). At the initial stage, the author personally distributed the questionnaires to 600 respondents in Sabah; after data cleaning was completed, only 525 questionnaires were deemed usable. There are a few standard statistical tools available for data analyses, and this study employed PLS-SEM for this purpose.

\section{Results and Discussion Descriptive Results}

Table 2 presents the descriptive results of the demographic characteristics of the respondents. A total of $366(70 \%)$ respondents were female, while 159 (30\%) were female owners/directors. The age of the respondents ranges from 18 to above 65 years. About $1.0 \%$ of the respondents were between the ages of 18 and 20 years. Approximately $26 \%$ were between the ages of 21 and 34 years, while $41 \%$ were between the ages of 35 and 44 years. Meanwhile, 23\% were in the range of 45 to 54 years old, $8 \%$ were between 55 and 64 years old, and $1 \%$ of the respondents were above 65 years old.

The results indicate that $95.2 \%$ of the respondents' were micro-entrepreneurs, and $2.5 \%$ were directors, while $2.3 \%$ were managers. In regards to the respondents' level of education, $13 \%$ 
attended primary education, $59 \%$ attended secondary schools, $17 \%$ were diploma holders, $7 \%$ were degree holders, $2 \%$ were master's holders, and $2 \%$ were doctorate holders.

Table 2: Profile for Micro Entrepreneur

\begin{tabular}{lcc}
\hline Variables & Frequency & Per cent \\
\hline Gender & 159 & \\
Male & 366 & 30.0 \\
Female & 525 & 70.0 \\
Total & & $\mathbf{1 0 0 . 0}$ \\
\hline Age & 5 & \\
18-20 & 139 & 1.0 \\
21-34 & 214 & 26.0 \\
35-44 & 123 & 41.0 \\
45-54 & 41 & 23.0 \\
55-64 & 3 & 8.0 \\
Above 65 & 525 & 1.0 \\
Total & & 100.0 \\
\hline Role in Business & 500 & \\
Owner & 13 & 95.2 \\
Director & 12 & 2.5 \\
Others & $\mathbf{5 2 5}$ & 2.3 \\
Total & & $\mathbf{1 0 0 . 0}$ \\
\hline Education & 69 & 13 \\
Primary School & 310 & 59 \\
Secondary School & 91 & 17 \\
Diploma & 36 & 7 \\
Degree & 11 & 2 \\
Master & 85.0 \\
Doctorate & & \\
Total & 525 & \\
\hline
\end{tabular}

\section{Data Analysis}

Least partial least squares (PLS) modelling using SmartPLS updated version of 3.3.2 (Ringle et al., 2020) was applied as the statistical tool to examine the measurement model and structural model. This technique was selected because it does not require normality assumption as survey research is usually not normally distributed (Chin et al., 2003). Since data was collected using a single source, the researcher began by testing the issue of common method bias following the suggestion of Kock and Lynn (2012), and Kock (2015) by testing full collinearity. In this method, all the variables will be regressed against a common variable; if the VIF $\leq 3.3$, then there is no biased from a single-source data. The analysis yielded VIF less than single-source bias; however, it is not a major issue for our data.

\section{Measurement Model Assessment}

The researcher follows the suggestion of Anderson and Gerbing (1988), which is to test the developed model using a 2-step approach. First, the researcher tested the measurement 
model for the validity and reliability of the instruments used following the guidelines of Hair et al., (2019) and Ramayah et al. (2018). Next, the researcher ran the structural model to test the hypotheses developed. For the measurement model, the researcher assessed the loadings, average variance extracted (AVE), and the composite reliability (CR). The values of loadings should be $\geq 0.5$, the AVE should be $\geq 0.5$, and the CR should be $\geq 0.7$. As shown in Table 5, all values of AVE were higher than 0.5, and the CRs were all higher than 0.7. Convergent validity is the extent to which a measure correlates positively with an alternative measure of the same construct. Convergent validity is evaluated by looking at the outer loadings of the indicators and the Average Variance Extracted (AVE).

Since Innovation items 01 and business performance indicator item 07 showed values below 0.5 AVE, the items were deleted, and the PLS Algorithm was rerun to analyse and recheck the result. Thus, indicators with loadings lower than 0.708 were retained when the minimum AVE result of 0.5 is achieved (Hair et al., 2019). However, there is a caution; deletion should not be more than $20 \%$ of the indicators in the model (Hair, Babin and Kerry, 2017; Hair et al., 2010). AVE should exceed 0.5 to suggest adequate convergent validity (Bagozzi and Yi, 1998; Fornell and Larker, 1981). The loadings were also acceptable, with only one or two loadings were less than 0.708 (Hair et al., 2019). Figure 2 illustrates the measurement model assessment.

Table 5: Measurement Model Assessment

\begin{tabular}{|c|c|c|c|c|c|}
\hline Construct & Item & Loadings & $\mathrm{CR}$ & AVE & $\begin{array}{c}\text { CV (Ave > } \\
0.5)\end{array}$ \\
\hline \multirow[t]{8}{*}{$\mathrm{BP}$} & BUPE1 & 0.784 & 0.855 & 0.888 & 0.506 \\
\hline & BUPE2 & 0.851 & & & \\
\hline & BUPE3 & 0.829 & & & \\
\hline & BUPE4 & 0.534 & & & \\
\hline & BUPE5 & 0.554 & & & \\
\hline & BUPE6 & 0.803 & & & \\
\hline & BUPE8 & 0.714 & & & \\
\hline & BUPE9 & 0.524 & & & \\
\hline \multirow[t]{4}{*}{ INNO } & INO2 & 0.725 & 0.740 & 0.833 & 0.554 \\
\hline & INO3 & 0.785 & & & \\
\hline & INO4 & 0.739 & & & \\
\hline & INO5 & 0.727 & & & \\
\hline \multirow[t]{3}{*}{$\mathrm{PC}$} & PCR1 & 0.855 & 0.814 & 0.889 & 0.728 \\
\hline & PCR2 & 0.884 & & & \\
\hline & PCR3 & 0.820 & & & \\
\hline
\end{tabular}

*BUPE7, INO1 items were deleted as loading Composite Reliability <.708 (Hair et al., 2019) 


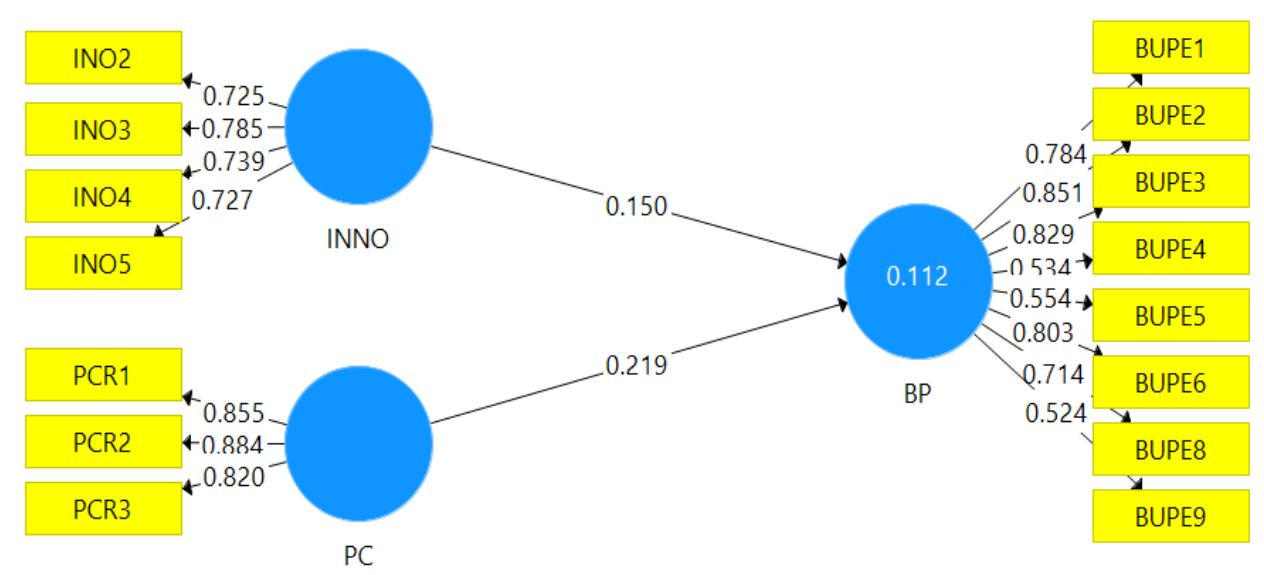

Figure 2: Measurement Model

In step 2, the researcher assessed the discriminant validity using the HTMT criterion suggested by Hair et al. (2019), as presented in Table 6 (Ringle et al., 2020). For the assessment of the discriminant validity, this study applies Henseler's (2015) heterotraitmonotrait ratio of correlations criterion. The findings reveal that the discriminant validity is well-specified at HTMT0.85 (Diamantopoulos and Siguaw, 2006). The results suggest that the correlation values corresponding to the respective constructs follow the most conservative criterion (HTMT.85), which implies that the discriminant validity issue is not a concern. The findings specified that it is appropriate to proceed with the structural model assessment to examine the hypotheses of the study as there is no issue of multi-collinearity between items loaded on different constructs in the outer model.

Table 6: Measurement Model Assessment

\begin{tabular}{cccc}
\hline & BP & INNO & PC \\
\hline BP & & & \\
INNO & 0.331 & & \\
PC & 0.353 & 0.822 & \\
\hline
\end{tabular}

Criteria: Discriminant validity is established at HTMT0.85

(Diamantopoulos \& Sigauw, 2006)

\section{Structural Model}

We conduct a 5000-bootstrap resampling of data to examine the hypotheses (Hair et al., 2017). Table 7 shows that the Beta values for each path coefficient specify that innovation and personal control positively influence the business performance of micro-entrepreneurs in Sabah. As shown in Table 7, both the proposed relationships $(\mathrm{H} 1-\mathrm{H} 2)$ significantly influence business performance among micro-entrepreneur. Specifically, the study found support for $\mathrm{H}_{1}$ (innovation $\rightarrow$ business performance, $\beta=0.150, p<0.008, \mathrm{LLCl}=0.032, \mathrm{ULCl}=0.241$ ) and $\mathrm{H}_{2}$ (personal control $\rightarrow$ business performance, $\beta=0.219, p<0.000, \mathrm{LLCl}=0.108, \mathrm{ULCl}=0.309$ ). Figure 3 shows the illustration of the structural model assessment. 
Table 7: Path Coefficients

\begin{tabular}{lccccccc}
\hline \multicolumn{1}{c}{ Direct Effect } & Beta & S.E. & t-value & p-value & LLCI & ULCI & Decision \\
\hline H1: INNO -> BP & 0.150 & 0.062 & 2.476 & 0.008 & 0.032 & 0.241 & Supported \\
H2: PC -> BP & 0.219 & 0.061 & 3.494 & 0.000 & 0.108 & 0.309 & Supported \\
\hline
\end{tabular}

Path Coefficient 0.01, 0.05 (Hair et al. 2017)

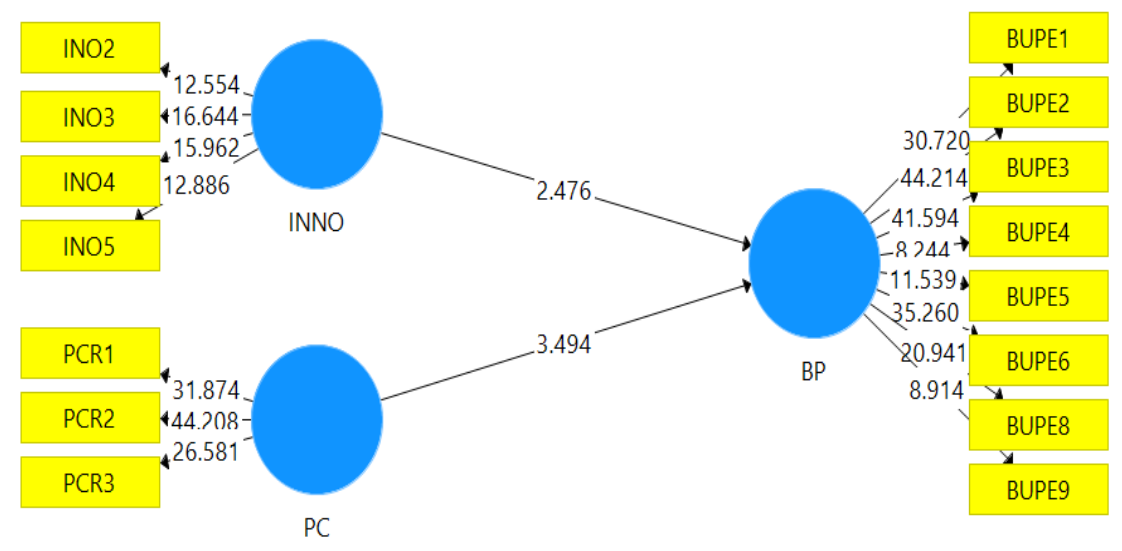

Figure 3: Structural Model

As suggested by Hair et al., (2017) and Cain et al., (2017), the assessment of the structural model for collinearity is not an issue if all the inner VIF values of the independent variable (Innovation and Personal Control) are less than 5 or 3.3 (Hair et al., 2017). Next, the significance and relevance of the structural model relationship were assessed. This is done by looking at the path coefficient after bootstrapping and evaluating the level of R-Square (coefficient) to predict the accuracy of the model and used as the cumulative influence of exogenous variables on the endogenous variable(s). In other words, $R^{2}$ reflects the sum of variation in the endogenous system described by all of the associated exogenous constructs. The impact ranges from 0 to 1 , with higher values indicate higher predictive accuracy rates. As several disciplines adopt $\mathrm{R}^{2}$, scholars are advised to focus on the "raw" rule of thumb in favour of a suitable $R^{2}$. There are three different rule of thumb laws for appropriate $R^{2}$.

1. Where $0.26,0.13,0.02$ represent significant, moderate, or low levels of predictive precision, respectively (Cohen, 1988),

2. Where $0.67,0.33,0.19$ represent significant, moderate, or low levels of predictive accuracy, respectively (Chin, 1998), and

3. Where $0.75,0.50,0.25$, represent significant, moderate, or low levels of predictive precision, respectively (Hair et al., 2017). Falk and miller (1992) propose that $R^{2}$ values equivalent to or greater than 0.10 are to be considered appropriate for the described variance of a given endogenous model.

Table 8 exhibits the assessment of model quality. We assess the coefficient of determination $\left(R^{2}\right)$, the effect size $\left(f^{2}\right)$ and the predictive relevance $\left(Q^{2}\right)$ of exogenous variables (on the endogenous variable of this study. Innovation and personal control revealed to carry small effect size $f^{2}$ on the micro-entrepreneur business performance (Cohen, 1988). The coefficient of determination represented by $\mathrm{R}^{2}$, which explains whether innovation and personal control could influence business performance, indicate moderate effects (Chin, 1998). Specifically, the $R^{2}$ value for innovation is 0.112 , suggesting that innovation and personal control could explain micro-entrepreneur business performance moderately. Multi-collinearity between indicators were also assessed. Both indicators satisfied the VIF values, and there were 
consistently below the threshold value of 5.0 (Hair et al., 2014) and 3.3 (Diamantopoulos and Siguaw, 2006). Thus, it can be concluded that collinearity issues do not exceed the critical levels in all variables, and therefore, are not an issue for the estimation of the PLS path model. The predictive relevance values of innovation and personal control towards microentrepreneur business performance are considered small, as shown by the value of 0.051 , presented by $Q^{2}$ using the blindfolding procedure (Hair et al., 2017).

Table 8: Model Quality Assessment

\begin{tabular}{lcccc}
\hline \multicolumn{1}{r}{ Direct Effect } & $\mathrm{f}^{2}$ & $\mathrm{R}^{2}$ & $\mathrm{VIF}$ & $\mathrm{Q}^{2}$ \\
\hline $\mathrm{H} 1: \mathrm{INNO}->\mathrm{BP}$ & 0.015 & 0.112 & 1.667 & 0.051 \\
$\mathrm{H} 2: \mathrm{PC} \rightarrow \mathrm{BP}$ & 0.032 & & 1.667 & \\
\hline
\end{tabular}

Lateral Collinearity: VIF 3.3 or higher (Diamantopoulos \& Siguaw, 2006)

$R 2 \geq 0.26$ consider Substantial (Cohen, 1989)

F2 $\geq 0.26$ consider Substantial (Cohen, 1989)

$Q^{2}>0.00$ consider large (Hair, 2017)

$0.02 \leq Q^{2}<0.15$ : weak predictive power

$0.15 \leq Q^{2}<0.35:$ moderate predictive power

$Q^{2} \geq 0.35$ : strong predictive power

\section{Discussions}

The findings of this study reveal that innovation and personal control did influence microentrepreneurs business performance. However, more effort needs to be done to improve its effectiveness as more and more SMEs who received the funds failed within three years of their operations. A study on the positive and significant relationship between innovation and business performance by Brown and Eisenhardt (1998) highlighted that innovative business could generate substantial economic performance due to its ability to create and introduce new products and technologies.

Likewise, Najib and Kiminami (2011) found a positive relationship between innovation and business performance. The findings of the present study are also in line with several other studies (Deshpande, Farley, Fredick and Webster, 1993; Baldwin and Johnson, 1996 and Salavou, 2002). Similarly, the findings of a study by Yahya, Pervan and Xu (2013) on SME firms in Dubai have confirmed that innovation has a significant and positive relationship with business performance. Other researchers, such as Keskin (2006) and Otero -Neira, Lindman and Fernandez (2009) also revealed a significant and positive relationship between innovation and business performance.

However, a small number of studies have shown the opposite findings. A study by Chang and Robin (2008) on 23 sectors of the manufacturing industry in Taiwan found a significant and negative relationship between innovation and business performance. Studies by Keling (2017) and Simpson, Siguaw, and Enz (2006) also show a significant and negative relationship between innovation on business performance. In their study, Yun Lin and Chen (2007) also found that innovation has no significant influence on business performance. Based on the above discussion, it can be concluded that the relationship between innovation and business performance is inconsistent. 
The study by Ismail et al. (2013) found that innovation is one of the crucial factors in entrepreneurial attitudes. Although the definition of innovation varies, the current study adopts the definition that describes innovation as the ability of micro-traders in Sabah to innovate or apply technology and practices towards product production and service delivery. In Sabah, the observed respondents seem to be ready to use the technology introduced by the relevant agencies. This attitude suggests that they have the intention to change their habits. Nevertheless, Ibrahim and Saili (2017) concluded that many entrepreneurs were still feeling less confident to innovate, despite their awareness that innovation would increase profits in the long run. Yet, the short-term commitment of loan repayment to relevant agencies is a primary concern.

Personal control, also known as locus of control, refers to a person's belief in the extent to which they can influence their outcome or success. The results show that self-control among micro-entrepreneurs in Sabah has a significant influence and relationship with high business performance compared to innovation; as personal control increases, the tendency towards entrepreneurship will also increase proportionally. The result is similar to a survey conducted by Bulut and Sayin (2010), whereby they found that individuals with high personal control are likely to succeed in business. Notably, decision-makers need to be highly confident, with a strong mental focus and be aware of what and where decisions will change. Increasing the level of inner thinking can improve their ability or motivate them to produce better results to increase profits. Meanwhile, Mekonnen and Gerber (2015) found the relationship between personal control and innovation dimension, which demonstrates that a successful entrepreneur has the confidence, ability, and capability to adapt to new technologies.

Overall, micro-entrepreneurs' level of practice of innovation and personal control in their business is at a moderately low level. Micro-entrepreneurs' approach in carrying out innovative business is influenced by their tendency to do so. The tendency to take action and achieve targets is influenced by the entrepreneur personal control and the support from the supervisory agency. Micro-entrepreneurs' strategies should include observing, comparing and improving by learning from competitors' products and services. In the business world, such a strategy is not considered "confidential" for producing different products or services from competitors (Baharuddin, 2009). This strategy will help entrepreneurs to design or develop products or services that are different and unique. Entrepreneurs need to formulate plans to develop products or services, able to identify products or services that suit the needs of customers and enterprises. Therefore, the government and stakeholders need to develop initiatives that will strengthen the relationships between innovation and self-control with business performance.

\section{Conclusion}

This study aims to examine the relationship between innovation,personal-control and microbusiness performance. However, the level of innovation and personal control among microentrepreneurs in Sabah is still at a moderate level. They need to diversify new ideas and continuously find new ways to expand their business targets further uniquely and effectively. Micro entrepreneurs also need to set even higher visions in developing new products and services are different and have their own special features. Such an attitude is critical to ensure that the level of business performance is always high, continue to compete and succeed. Thus, the problem of failure to compete in the early stages of business can be avoided. 
This study's findings provide a deeper understanding of factors influencing the performance of micro-businesses and further enrich the empirical studies, especially in the field of entrepreneurship. In general, this study explains the role of innovation and personal-control in improving business performance among micro-enterprises in Malaysia. The results of this study also beneficial to stakeholders of micro-enterprises, namely the government and related agencies, by inspiring new approaches and implementing suitable programmes, particularly to address the problems faced by micro-entrepreneurs.

The findings of the study also further contribute to the body of literary, specifically in the field of entrepreneurship and micro-enterprises' performance. This study only proposes a conceptual research framework involving innovation and personal control with micro business performance. The results of previous works show that this study should be continued as there is still an inconsistent relationship between innovation and micro-business performance.

In conclusion, attitudes towards entrepreneurship and towards innovation and personalcontrol influence individuals' tendency to improve the performance of their businesses. If attitudes towards change and innovation are negative, business performance will not improve. However, there are some difficulties in determining whether this is a causative relationship (i.e., that a positive attitude towards entrepreneurship creates a higher level of entrepreneurship) or rather a higher level of entrepreneurship creates a better attitude, or whether both are symptoms of other factors. We can assume that different social, cultural, political and geographical factors influence the level of enterprise and attitude towards entrepreneurship; to some extent, it obscures the direct impact that may be due to a change in attitude. In a nutshell, the results of this study conformed to the literature that entrepreneurial attitudes, namely innovation and personal control, have a positive relationship with business performance.

\section{Limitation and Study Forward}

As with other research works, this study also has some limitation: first, the inherent weaknesses in the use of questionnaires as data collection instruments (Saunders et al., 2000). Second, this study considers micro-businesses in general, without separating them into sectors and levels of development. The results may be different if micro-businesses are separated according to sectors and development level. Therefore, this study recommends that future studies consider splitting micro-businesses into appropriate sectors, and according to the stage of development. Future studies should use other performance measures to enrich the understanding of the relevance of entrepreneurial attitude orientation to business performance, particularly in the state of Sabah.

\section{References}

Abdullahi, A. I., \& Zainol, F. A. (2016). The impact of socio-cultural business environment on entrepreneurial intention: A conceptual approach. International Journal of Academic Research in Business and Social Sciences, 6(2), 80-94

Ahmad, H., Ahmad, K., \& Ali Shah, I. (2010). Relationship between Job Satisfaction, Job Performance Attitude towards Work and Organisational Commitment. European Journal of Social Science, 18(2), 257-267 
Ajzen, I., \& Fishbein, M. (1987). Understanding attitudes and predicting social behaviour, Englewood Cliffs: Prentice Hall.

Alhnaity, Haitham. (2018). "The influence of Entrepreneurial Attitude on ERAD' Small Businesses Performance as Moderating by Government Intervention.

Allport, G. W. (1935). Attitudes. In C. Murchison (Ed.), Handbook of social psychology, pp. 798884. Worcester, MA: Clark University.

Anderson, J. C., \& Gerbing D. W. (1988). Structural Equation Modeling in Practice: A Review andRecommended Two-Step Approach. Psychological Bulletin, 103, 411-423. http://dx.doi.org/10.1037/0033-2909.103.3.411

Antonic, B., \& Hisrich, R. D. (2003). Clarifying the intrapreneurship concept. Journal of Small Business and Enterprise Development, 10 (1): 7-24.

Arisi-Nwugballa, E. A., Elom, M. E., \& Onyeizugbe, C. U. (2016). Evaluating the relevance of

Entrepreneurial Orientation to the Performance of Micro, Small and Medium Enterprises in Ebonyi State, Nigeria. International Journal of Academic Research in Accounting, Finance and Management Sciences, 6, 221-230. DOI:10.6007/IJARAFMS/v6-i3/2257

Baharuddin, I. (2009). Asas Pengurusan Pemasaran. Shah Alam, Selangor: Pusat Penerbitan Universiti (UPENA), Universiti Teknologi MARA

Bakar, M. S., Ramli, A. Bin, Ibrahim, N. A., \& Muhammad, I. G. (2017). Entrepreneurial SelfEfficacy Dimensions and Higher Education. International Journal Management Sciences, 24(September), 119-137.

Baldwin, J. R., \& Johnson, J. (1996). Business strategies in more- and less-innovate firms in Canada. Research Policy, 25(5), 785-804.

Bagozzi, R. P., \& Yi, Y. (1988). On the evaluation of structural equation models. Journal of the academy of marketing science, 16(1), 74-94. DOI: 10.1007/BF02723327

Begley, T. M., Boyd, D. (1987). Psychological characteristics associated with performance in entrepreneurial firms and small businesses. Journal of Business Venturing 2, 79-93

Breckler, S. J. (1984). Empirical validation of affect, behavior, and cognition as distinct components of attitude. Journal of Personality and Social Psychology, 47(6), 11911205. https://doi.org/10.1037/0022-3514.47.6.1191

Brown, S. L., \& Eisenhardt, K. M. (1998). Competing on the edge. Boston: Harvard Business School Press

Bulut, Y., \& Sayin, E. (2010). An evaluation of entrepreneurship characteristics of university students: An empirical investigation from the Faculty of Economic and Administrative Sciences in Adnan Menderes University. International Journal of Economic Perspectives, 4(3), 559-568.

Cain, M. K., Zhang, Z., \& Yuan, K. H. (2017). Univariate and multivariate skewness and kurtosis for measuring nonnormality: Prevalence, influence and estimation. Behavior research methods, 49(5), 1716-1735.

Chaiken, S., \& Stangor, C. (1987). Attitudes and attitude change. Annual Review of Psychology, $38,575-630$.

Chang, C., \& Robin, S. (2008). Public policy, innovation and total factor productivity: an application to Taiwan's manufacturing industry. Mathematics and Computers in Simulation, 79(3), 352-367

Chin, W. W. (2003), PLS-Graph 3.0, Soft Modeling Inc, Houston.

Chin, W. W. (1998). The partial least squares approach to structural equation modeling. Modern methods for business research, 295(2), 295-336.

Chin, Y. W., \& Lim, E. S. (2018). SME Policies and Performance in Malaysia. 
Choe, K. L., Loo, S. C., \& Lau, T. C. (2013). Exploratory study on the relationship between entrepreneurial attitude and firm's performance. Asian Social Science, 9(4), 144-149.

Cohen, J. (1988). Statistical Power Analysis for the Behavioral Science (2nd ed.). Hillsdale NJ: Lawrence Erlbaum Associates.

Cooper, A. C., \& Gascon, E. J. G. (1992). Entrepreneurs, processes of founding, and new-firm performance, in the state of art of entrepreneurship, edited by DL Sexton \& JD Kassadra. Boston: PWS-Kent.

Covin, J. G., \& Wales, W. J. (2012). The measurement of entrepreneurial orientation. Entrepreneurship Theory and practice,36(4),677-702

Davidson, P. (1995). Determinant of entrepreneurial intentions. Paper presented in RENT IX Workshop in entrepreneurship research, Piacenza. Italy between (23-24 Nov. 1995. hhtp://www.ihh.seleng/research.publication/wp 1995-1996 Davidson pdf 17-05-2005.

Diamantopoulos, A., \& Siguaw, J. A. (2006). Formative versus reflective indicators in organisational measure development: A comparison and empirical illustration. British Journal of Management, 17(4), 263-282.

Din, M. S., Hoe, C. H., Hashim, N., Ooi, Y. K., Ahmad, S., Bakar, H., ... Md Hussain, M. N. (2005). Asas Keusahawanan. Kuala Lumpur: Prentice Hall.

Deshpande, R., Farley, J. U., Fredick, E., \& Webster, J. (1993). Corporate culture, customer orientation and innovatiness in Japan firms: a quadrad analysis. Journal of Marketing, 57(1), 23-38.

Drucker, P. F. (1985). Innovation and Entrepreneurship: Practice and principles. New York: Harper and Row.

Douglas, E. J., Shepherd, D. A. (2000). Entrepreneurship as a utility maximising response. J. Bus. Venture. 15, 231-251.

Faul, F., Erdfelder, E., Lang, A.-G., \& Buchner, A. (2007). G*Power 3: A flexible statistical power analysis program for the social, behavioral, and biomedical sciences. Behavior Research Methods, 39, 175-191.

Fidell, L. S., \& Tabachnick, B. G. (2003). Preparatory data analysis. Handbook of Psychology: Volume 2 Research Methods in Psychology.

Fornell, C., \& Larcker, D. F. (1981). Evaluating structural equation models with unobservable variables and measurement error. Journal of Marketing Research, 18(1), 3950. https://doi.org/10.2307/3151312

Godwin, B. A., \& Okoronka, U. A. (2015). Attitude and Academic Performance of Senior Secondary School Students in Physics in Nigeria. International Conference on Education, Social Sciences and Humanities, (June), 499-508.

Hair, J. F., Anderson, R. E., Babin, B. J., \& Black, W. C. (2010). Multivariate data analysis: A global perspective (Vol. 7). Upper Saddle River, NJ: Pearson.

Hair, J. F., Hult, G. T. M., Ringle, C. M., \& Sarstedt, M. (2014). A Primer on Partial Least Squares Structural Equation Modeling (PLS-SEM). Thousand Oaks, California: Sage Publications.

Hair, J. F., Hult, G. T. M., Ringle, C. M., Sarstedt, M., \& Thiele, K. O. (2017). Mirror, mirror on the wall: A comparative evaluation of composite-based structural equation modelling methods. Journal of the Academy of Marketing Science, 45, 616-632.

Hair, J. F., Risher, J. J., Sarstedt, M., \& Ringle, C. M. (2019). When to use and how to report the results of PLS-SEM. European Business Review. DOI: 10.1108/EBR-11-2018-0203

Hayduk, L. A., \& Littvay, L. (2012). Should researchers use single indicators, best indicators, or multiple indicators in structural equation models? BMC Medical Research Methodology, 12, 159. 
Henseler, J., Ringle, C. M., \& Sarstedt, M. (2015). A new criterion for assessing discriminant validity in variance-based structural equation modeling. Journal of the academy of marketing science, 43(1), 115-135.

Luu, H. (2011). The Relationship between Employee Attitudes and Organisational Performance: Evidence from Cooperative Retail Stores.

Hogg, M. A., \& Cooper, J. (2007). Sage handbook of social psychology. London: Sage Publications.

Ismail, K., Omar, W. Z. W., Soehod, K., Senin, A. A., \& Akhtar, C. S. (2013). Role of Innovation in SMEs performance: A case of Malaysian SMEs. Mathematical Methods in Engineering and Economics, 145-149.

Jain, R., \& Ali, S. W. (2013). Self-Efficacy Beliefs, Marketing Orientation and Attitude Orientation of Indian Entrepreneurs. The Journal of Entrepreneurship, 22(1), 71-95.

Jain, R., Ali, S. W., \& Kamble, S. (2015). Entrepreneurial and intrapreneurial attitudes: Conceptualisation, measure development, measure test and model fit. Management and Labour Studies, 40(1-2), 1-21.https://doi.org/10.1177/0258042X15601529

Jelenc, L., Pisapia, J., \& Ivancic, V. (2016). Strategic Thinking Capability and Entrepreneurial Attitude Orientation: Links and Relations. Available at SSRN 2794656.

Khalid, N. (2020). Artificial intelligence learning and entrepreneurial performance among university students: evidence from malaysian higher educational institutions. Journal of Intelligent \& Fuzzy Systems, (Preprint), 1-19.

Kagaari, J. R., Munene, J. C., \& Ntayi, J. M. (2010). Performance management practices, information and communication technology (ICT) adoption and managed performance. Quality assurance in education. https://doi.org/10.1108/09684881011035330

Keling, W., \& Entebang, H. (2017). Entrepreneurial Attitude Orientation (EAO) and indigenous dayak entrepreneurs (de) performance in Sarawak. Managing Transformation in Technology and Innovation Globalization, 175.

Keskin, H. (2006). Market orientation, learning orientation and innovation capabilities in SMEs: an extended model. European Journal of Innovation Management, 9(4), 396- 417

Khan, I., Dongping, H., \& Ghauri, T. A. (2014). Impact of attitude on employees performance: a study of textile industry in Punjab, Pakistan. World Applied Sciences Journal, 30(1), 191-197. DOI: 10.5829/idosi.wasj.2014.30.icmrp.25

Koh, C. H. (1996). Testing hypotheses of entrepreneurial characteristics: A study of Hong Kong MBA students. Journal of Managerial Psychology, 11(3),12-25

Kollmann, T., Christofor, J., \& Kuckertz, A. (2007). Explaining individual entrepreneurial orientation: Conceptualisation of a cross-cultural research framework

Kock, N. (2015). Standard method bias in PLS-SEM: A full collinearity assessment approach. International Journal of e-Collaboration (ijec), 11(4), 1-10.

Krueger, N. F., Reilly, M. D., \& Carsrud, A. L. (2000). Competing models of entrepreneurial intentions. Journal of Business Venturing, 15, 411-432.

Kuratko, F., \& Hodgetts, M. (2004). Entrepreneurship - Theory, Process Practice. (Eds) Australia: Thomson South-Western.

Lai, Y., Saridakis, G., \& Johnstone, S. (2017). Human resource practices, employee attitudes and small firm performance. International Small Business Journal, 35(4), 470-494. DOI: $10.1177 / 0266242616637415$

Lee, M., \& Peterson, J. (2000). Culture, Entrepreneurial Orientation, And Global Competitiveness (Analysis Of Relationship Between Culture And Entrepreneurship), 
Journal of World Business, 35(4), 401-416

Li, Y. H., Huang, J. W., \& Tsai, M. T. (2009). Entrepreneurial orientation and firm performance: The role of knowledge creation process. Industrial marketing management, 38(4), 440449.

Low, M., \& MacMillan, I. (1988). Entrepreneurship: Past Research and Future Challenges. Journal of Management, 14(2), 139-161.

McClelland, D. C. (1961). The Achieving Society. Princeton NJ: Van Nostrand.

Mekonnen, D. A., \& Gerber, N. (2016). The effect of aspirations on agricultural innovations in rural Ethiopia. Retrieved from https://ssrn.com/abstract $=2777383$

Mohamad, A., Rizal, A. M., Quoquab, F., Juhdi, N. H., \& Sahimi, M. (2016). Restarting after Business Discontinuity among Bumiputra Small and Medium Enterprises. European Journal of Economics and Business Studies, 1(2), 259-270.

Murphy, G. B., Trailer, J. W., \& Hill, R. C. (1996). Measuring performance in entrepreneurship research. Journal of business research, 36(1), 15-23.

NSDC (2017). SME Annual Report 2016/2017. September 2017. Retrieved from http://www.smecorp.gov.my/index.php/en/laporan-tahunan/2150-sme-annualreport-2016-17

Olson, P. D., \& Bosserman, D. A. (1984). Attributes of the Entrepreneurial Type. Business Horizons.

Otero-Neira, C., Lindman, M., \& Fernandez, M. (2009). Innovation and performance in SME furniture industries. an international comparative study. Marketing Intelligence \& Planning, 27(2), 216-232. doi 10.1108/EBS-04-2013-0012

Phan, P. H., \& Butler, J. E. (2003). Entrepreneurs' attitudes, strategy choices, and firm performance. Journal of business and entrepreneurship, 15(1), 74-91.

Pickens, J. (2005). Attitudes and Perceptions. Organisational Behavior in Health Care, 43-75.

Politis, D., \& Gabrielsson, J. (2007). Entrepreneurs' attitudes towards failure-An experiential learning approach. Frontiers of Entrepreneurship Research. DOI: $10.1108 / 13552550910967921$

Pulka, B. M. (2018). the multidimensional impact of entrepreneurial attitude orientation on firm performance: a study of micro enterprises in Maiduguri, Borno state, Nigeria. Nigerian journal of accounting and finance, 10(1).

Rauch, A., Wiklund, J., Lumpkin, G. T., \& Frese, M. (2009). Entrepreneurial orientation and business performance: An assessment of past research and suggestions for the future. Entrepreneurship theory and practice, 33(3), 761-787.

Ricard, A., \& Saiyed, A. A. (2015). Attitude toward internationalisation and early internationalisation:

Comparison of Indian and French S.M.E.s' decision makers. Management (France), 18(1), 5477.

Ringle, C. M., Wende, S., and Will, A. (2005), SmartPLS 2, SmartPLS, Hamburg

Ringle, C., Wende, S., \& Will, A. (2020). SmartPLS 3.3.2. Retrieved from http://www.smartpls.com

Robinson, P. B., Stimpson, D. V., Huefner, J. C., \& Hunt, H. K. (1991). An attitude approach to the prediction of entrepreneurship. Entrepreneurship Theory and Practice, 15(4), 13-31.

Roldán, J. L., \& Sánchez-Franco, M. J. (2012). Variance-based structural equation modeling: Guidelines for using partial least squares. In M. Mora, O. Gelman, A. L. Steenkamp, \& M. Raisinghani (Eds.), Research methodologies, innovations and philosophies in 
software systems engineering and information systems (pp. 193-221). Hershey, PA: IGI Global.

Rotter, J. B. (1966). Generalised expectancies for internal versus external control of reinforcements. Psychological Monographs, 80(1), 1-28.

Salavou H. (2002). Profitability in market oriented SMEs: does product innovation matter? European Journal of Innovation Management, 5(3), 164-171

Samuel, Y. A., Ernest, K., \& Awuah, J. B. (2013). An assessment of Entrepreneurship intention among Sunyani Polytechnic Marketing students. International Review of Management and Marketing, 3(1), 37-49.

Shahab, M. A., \& Nisa, I. (2014). The Influence of Leadership and Work Attitudes toward Job Satisfaction and Performance of Employee. International Journal of Managerial Studies and Research (IJMSR), 2(5), 69-77.

Simpson, P. M., Sigwau J. A., \& Enz, C. A. (2006). Innovation orientation outcomes. The good and the bad. Journal of Business Resources, 59, 1131-1141.

Shaver, K. G. (1987). Principles of social psychology (3rd ed.). Cambridge, MA: Winthrop.

Strauss, J. P. (2005). Multi-source perspectives of self-esteem, performance ratings, and source agreement. Journal of Managerial Psychology, 20(6), 464-482.

Suliyanto, \& Rahab. (2012). The role of market orientation and learning orientation in improving innovativeness and performance of small and medium enterprises. Asian Social Science, 8(1), 134-145.

Susanty, A., Miradipta, R., \& Jie, F. (2013). Analysis of the effect of attitude toward works, organisational commitment, and job satisfaction, on employee's job performance. European Journal of Business and Social Sciences, 1(10), 15-24. DOI: 10.9744/jti.15.1.13-24

Valliere, D. (2006). Consequences of growth: Shaping entrepreneurial attitudes. The International Journal of Entrepreneurship and Innovation, 7(3), 141-148. https://doi.org/10.5367/000000006778026626

Vasconcelos, R., \& Oliveria, M. (2018). Does innovation make a difference?. Innovation \& Management Review.

Wiklund, J., \& Shepherd, D. (2003). Knowledge-based resources, entrepreneurial orientation, and the performance of small and medium-sized businesses. Strategic management journal, 24(13), 1307-1314. https://doi.org/10.1002/smj.360

Yun Lin C. Y., \& Chen. M. Y. (2007). Does innovation lead to performance? An empirical study of SMEs in Taiwan. Management Research News, 30(2), 115-132. doi:10.1108/01409170710722955. 